\title{
Binding of Diamine Oxidase Activity to Rat and Guinea Pig Microvascular Endothelial Cells \\ Comparisons with Lipoprotein Lipase Binding
}

\begin{abstract}
Audrey Robinson-White, Stephen B. Baylin, Thomas Olivecrona, and Michael A. Beaven
Laboratory of Chemical Pharmacology, National Heart, Lung, and Blood Institute, National Institutes of Health, Bethesda, Maryland 20205; Endocrine Oncology Laboratory, Oncology Center and Department of Medicine, The Johns Hopkins School of Medicine, Baltimore, Maryland 21205; and Department of Physiological Chemistry, University of Umea, Umea, Sweden
\end{abstract}

\begin{abstract}
Microvascular endothelial cells from rat and guinea pig fat pads were shown to bind diamine oxidase (DAO) activity when incubated with soluble extracts of placenta (33 DAO U/mg of placenta) and a purified placental enzyme preparation (94 U/ $\mu \mathrm{g}$ of protein). The extent of binding was dependent on the concentration of enzyme activity and tissue. Saturation of binding sites with $5,000 \mathrm{U}$ of $\mathrm{DAO} / \mathrm{ml}$ resulted in levels of bound activity (up to 11-13 $\mathrm{U} / \mathrm{mg}$ of endothelial cells) in excess of that observed in all tissues except placenta. Scatchard plots suggested that there were at least two DAO binding sites (apparent $K_{\mathrm{m}} 92$ and $2,450 \mathrm{U} / \mathrm{ml}$ ). Although the same cell preparations bound ${ }^{125}$ I-labeled lipoprotein lipase (LPL), the presence of LPL on the endothelial cell surface did not interfere with the binding of DAO activity except when cells were exposed to high concentrations of LPL. Alternatively, bound DAO activity was partially displaced (up to 33\%) only with high concentrations $(30 \mu \mathrm{g} / \mathrm{ml})$ of LPL. DAO activity may thus be bound to at least two populations of sites, one of which may bind LPL. Both enzymes, however, were displaced by heparin (0.05-5 $\mathrm{U} / \mathrm{ml})$ and DAO binding was impaired by prior treatment of cells with proteolytic and glycosaminoglycandegrading enzymes. The demonstration of DAO binding to vascular endothelial cells provides a further example of the ability of these cells to bind enzymes at their surface and thereby act on biologically active substances in the circulation.
\end{abstract}

\section{Introduction}

The enzyme diamine oxidase (EC 1.2.6) (DAO) ${ }^{1}$ catalyzes the deamination of histamine and diamines such as putrescine and cadaverine $(1,2)$. This enzyme plays a major role in histamine degradation in the rat and some other species (3, 4). DAO activity is produced in particularly high amounts by the maternal placenta $(5,6)$, and this results in large increases in enzyme activity in plasma (e.g., 7-11) and other tissues

Dr: Robinson-White is a Staff Fellow of the Pharmacology Research Associate Program (National Institute of General Medical Services). During the course of this work Dr. Olivecrona was a Visiting Scientist at the National Institutes of Health. Address reprint requests to Dr. Beaven, Bldg. 10, Rm. 8N 114, National Institutes of Health, Bethesda, MD 20205.

Received for publication 6 August 1984 and in revised form 7 January 1985.

1. Abbreviations used in this paper: DAO, diamine oxidase; DME, Dulbecco's modified Eagle's medium; LPL, lipoprotein lipase.

The Journal of Clinical Investigation, Inc.

Volume 76, July 1985, 93-100 (unpublished data) during pregnancy. In nonpregnant animals, the enzyme is released upon injection of heparin into the circulation of humans (12-14) and the rat, rabbit (15), and guinea pig $(15,16)$. Inasmuch as this release is apparent within $20 \mathrm{~s}$ (14) and because DAO activity is present in or on microvascular endothelial cells from rat and guinea pig (17), we have examined the possibility that heparin might act by displacement of DAO from vascular endothelial cells. By analogy, lipoprotein lipase (LPL) activity (EC 3.1.1.3) is released along with DAO activity into the circulation by heparin (13, 14), is bound to cultured endothelial cells from bovine pulmonary artery (18) and calf aorta (19), and is displaced from these cells by heparin from sites believed to contain heparan sulfate-like moieties (18-20).

Here we describe studies on the adherence of DAO activity and LPL to isolated rat and guinea pig microvascular endothelial cells (17) and the displacement of the two enzymes by heparin. We have defined the characteristics of DAO binding with both crude and purified DAO preparations from rat placental extracts.

\section{Methods}

Materials. Male Sprague-Dawley and, where indicated, Osborne-Mendel rats, $350-500 \mathrm{~g}$, pregnant Sprague-Dawley rats (15 d in term), and Piebald guinea pigs, $500-1,000 \mathrm{~g}$, were obtained from Division of Research Services, National Institutes of Health (Bethesda, MD). Drugs and reagents were obtained from the following sources: media (Grand Island Biological Co., Grand Island, NY); cystalline bovine serum albumin (Pentex bovine albumin, Miles Laboratories, Elkhart, IN); glucose, L-glutamine, bovine serum albumin-fraction V (Sigma Chemical Co., St. Louis, MO); collagenase type II, soybean trypsin inhibitor (Worthington Biochemical Corp., Freehold, NJ); heparin sodium, 1,000 USP U $(8.33 \mathrm{mg} / \mathrm{ml})$, (The Upjohn Co., Kalamazoo, MI); Percoll and density marker beads (Pharmacia Fine Chemicals, Piscataway, NJ); dioctyl- and dibutylphthalate (ICN Pharmaceuticals, Plainview, NY).

For the isolation and for studies with microvascular endothelial cell preparations, the following solutions were used: solution A contained Eagle's minimum essential medium amino acid solution $(\times 50), 50$ $\mathrm{ml} /$ liter; glucose, $14 \mathrm{mM}$; L-glutamine, $2 \mathrm{mM}$ and bovine serum albumin, $0.4 \% \mathrm{wt} / \mathrm{vol}$ in Dulbecco's phosphate-buffered saline ( $\mathrm{pH}$ 7.4) (17). Supplemented Dulbecco's modified Eagle's medium (DME) contained $5.5 \mathrm{mM}$ glucose in Dulbecco's phosphate-buffered saline.

Pronase (nonspecific protease from Streptococcus griseus; 77,000 proteolytic[PUK] units/g, as defined by manufacturer) was purchased from Calbiochem-Behring Corp. (La Jolla, CA) and heparinase (from Flavobacterium heparinum) was obtained from Seikaguki Kogyo Co. Ltd., Tokyo, Japan, through Miles Laboratories, Inc., Naperville, IL. The latter enzyme preparation, which had a specific activity of 320 conventional units (1.9 IU) per milligram of protein when heparin was used as a substrate, did exhibit some ( $<2 \%$ of its heparinase activity) lyase activity towards chondroitin sulfate $A$ and $C$, hyaluronic acid, and heparitin sulfate (manufacturer's literature). It has also been 
reported to us that the product is contaminated with protease activity (Hascall, V., personal communication).

Enzyme preparations and extracts. Human (postpartum) and rat (15-d term) placentas were stored at $-20^{\circ} \mathrm{C}$ and extracts were prepared daily as required. Tissues were homogenized in $11 \mathrm{vol}$ of supplemented DME. The homogenates were centrifuged $(2,000 \mathrm{~g}$ for $10 \mathrm{~min})$ and the supernatant fractions were collected. These extracts were diluted in supplemented DME $\left(4^{\circ} \mathrm{C}\right)$ as required.

DAO was purified from Sprague-Dawley rat placenta by modification of previously published procedures $(21,22)$. DAO activity in a $1: 3$ $(w t / v o l)$ homogenate of rat placenta $(100 \mathrm{~g})$ was purified 100 -fold by adsorption onto Sepharose-cadaverine and elution with heparin exactly as described (22). The enzyme activity was further purified (threefold) by passage through a $1 \times 22-\mathrm{cm}$ column of concanavalin $A$ bound to Sepharose 4B and elution with $0.6 \mathrm{M}$ mannose. This step separated DAO activity from heparin. The eluates that contained DAO activity (fractions $25-32 ; 10-\mathrm{ml}$ fractions) were pooled and concentrated to 2 $\mathrm{mi}$ in collodion bags (Schleicher \& Schuell, Inc., Keene, NH) under vácuum $(500 \mathrm{mmHg})$. Two batches of enzyme were prepared $(2.0 \mathrm{mg}$

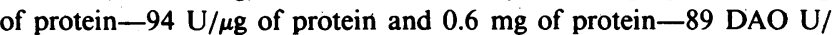
$\mu \mathrm{g}$ of protein) and used in the present studies to yield virtually identical data as noted in text. The above specific activities may be compared with that of the human placental enzyme preparation (150 DAO U/ $\mu \mathrm{g}$ of protein) which was assayed by the same techniques and substrate used here (22). Electrophoresis on sodium dodecyl sulfate-polyacrylamide $(7.5 \%)$ gels indicated one major $(97,000 \mathrm{~mol} \mathrm{wt})$ and one minor $(200,000 \mathrm{~mol} \mathrm{wt})$ protein band in the rat placental preparation (Fig.

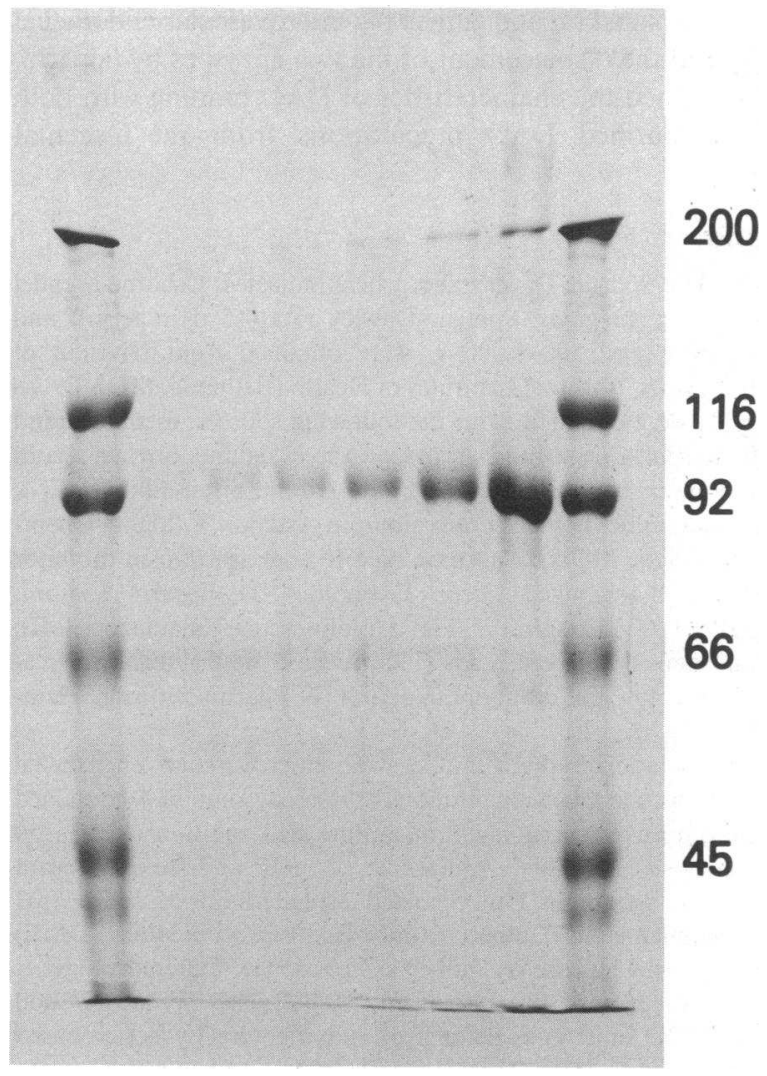

Figure 1. Electrophoretic patterns for purified rat placental DAO enzyme preparations $(0.25,0.5,1,2,4$, and $13 \mu \mathrm{g}$ of protein) and standard proteins (myosin, $\beta$-galactosidase, phosphorylase B, bovine serum albumin, ovalbumin; Bio-Rad Laboratories, Richmond, CA). Molecular weights are as indicated. Preparations were run on $7.5 \%$ polyacrylamide gel in $0.1 \%$ sodium dodecyl sulfate and stained with Coomassie Blue exactly as described (22).
1). The molecular weight of the major band, which constituted $\sim 85 \%$ of the total protein as estimated by gel scans (procedures were as described in reference 22), was similar to that of human placental DAO (22). Estimates of $K_{\mathrm{m}}$ for histamine for the rat placental enzyme (2.3 $\mu \mathrm{M}$, unpublished data) were similar to those of the human placental enzyme ( $3.2 \mu \mathrm{M}$, reference 22). Although there are indications of differences in immunologic cross-reactivity between human and rat DAO (22), cross-reactivity between the rat and human placental enzymes have not been determined.

LPL, isolated from bovine milk $(23)$, was stored $\left(-60^{\circ} \mathrm{C}\right)$ in 20 $\mathrm{mM}$ Tris chloride in $1.2 \mathrm{M}$ sodium chloride (pH 7.4). ${ }^{125} \mathrm{I}-\mathrm{LPL}$ was prepared by the lactoperoxidase procedure $(24,25)$ and purified by chromatography on Sepharose-heparin columns equilibrated in 20 $\mathrm{mM}$ Tris-chloride, $0.1 \%$ Triton X-100, 20\% (wt/vol) glycerol, $0.1 \%$ (wt/vol) bovine serum albumin ( $\mathrm{pH} 7.4$ ), and elution with a gradient of 0-2 $\mathrm{M}$ sodium chloride in the same medium. Before use, the enzyme preparations $(0.5-1.0 \mathrm{ml})$ were dialyzed $\left(2 \mathrm{~h}, 4^{\circ} \mathrm{C}\right)$ against two changes of supplemented DME. The enzyme preparations were diluted in supplemented DME with $0.1 \% \mathrm{wt} /$ vol Pentex bovine albumin. Specific activity of ${ }^{125} \mathrm{I}$-labeled LPL preparations ranged from 1.6 to $4.5 \mathrm{nCi} / \mathrm{ng}$ of protein.

Preparation of microvascular endothelial cells. Earlier protocols for the preparation of these cells from rat epididymal and guinea pig epididymal-perirenal fat pads (17) were modified by substituting Percoll for serum albumin gradients in the final separation step. Up to this step the procedures were exactly as described previously. Percoll gradients were prepared in $40-\mathrm{ml}$ tubes by centrifugation $(30,000 \mathrm{~g}$ for $60 \mathrm{~min}$ in an ultracentrifuge [model L8-55; Beckman Instruments, Inc., Fullerton, $\mathrm{CA}$ ] with an angle rotor head) of a $1+1$-part mixture of Percoll with solution A described above. Samples $(4 \times 2 \mathrm{ml})$ of the cell suspensions were carefully layered on top of four Percoll gradients. The tubes were centrifuged (model TJ-6 [Beckman Instruments, Inc.] in a swinging bucket head) at $1,000 \mathrm{~g}$. for $10 \mathrm{~min}$. From each tube, a band (density $1.048 \mathrm{~g} / \mathrm{ml}$ ) of endothelial cells was carefully removed from a lower layer of erythrocytes and transferred to a plastic tube before dilution with $10 \mathrm{ml}$ of supplemented DME. Cells were recovered by centrifugation ( $100 \mathrm{~g}$ for $3 \mathrm{~min}$ ), pooled, and then resuspended in the same medium to give $1 \mathrm{mg}$ of tissue $/ 50 \mu \mathrm{l}$ of suspension unless indicated otherwise. All centrifugations were at $4^{\circ} \mathrm{C}$.

All preparations were assayed for protein (17). Cell viability was assessed by the fluorescein diacetate/ethidium bromide dye exclusion technique (26). As in previous studies (17), the preparations consisted of segments of two to eight endothelial cells (95-100\% viable) with an occasional pericyte or smooth muscle cell attached. Electron microscopic examination ( 500 cells) indicated that endothelial cells accounted for $81 \%$ and $92 \%$ of the total cells present in rat and guinea pig preparations, respectively. Mast cells and adipocytes were not observed in these preparations. From estimates of protein and DNA content of preparations of rat fat pad microvascular endothelial cells (17), we calculated that each cell contained $80 \mathrm{pg}$ of protein. In the present studies, $1 \mathrm{mg}$ of wet cell pellet contained an average of $21 \pm 3 \mu \mathrm{g}$ of protein and an estimated $2.6 \times 10^{5}$ cells.

$D A O$ and LPL binding studies. For measurement of DAO binding, suspensions $(50 \mu \mathrm{l})$ of endothelial cells were incubated with DAO preparation or vehicle at $37^{\circ} \mathrm{C}$ in a total volume of $100 \mu \mathrm{l}$. The amounts of tissue and enzyme preparation and period of incubation were as noted in text and figure legends. The mixture was centrifuged $(500 \mathrm{~g} \text { for } 3 \mathrm{~min})^{2}$ to terminate the reaction. $80 \mu \mathrm{l}$ of the supernatant fraction was saved for DAO or LPL assays and the remainder was removed carefully to avoid disturbing the cell pellet. The cell pellet was washed twice in $100 \mu \mathrm{l}$ ice-cold supplemented DME before resuspension in $100 \mu \mathrm{l}$ of the same medium. To minimize cell breakage, cells were resuspended by gentle aspiration through a soft

2. Conditions for centrifugation were chosen to ensure minimal cell breakage $(<10 \%$ loss of cell protein or cell viability as determined by vital stains) and maximal recovery of cells. 
polyethylene 3-ml transfer pipette. The washing procedure was used exclusively in the present studies in that this procedure permitted recovery of cells for further incubation (see following section). Enzyme activity recovered from the cell pellet by washing was otherwise similar to that recovered from cells centrifuged through a mixture of dioctyland dibutylphthalate $(40+60$ parts $)$ at $10,000 \mathrm{~g}$ for $1 \mathrm{~min}$. The residual DAO activity appeared to be tightly bound as discussed later. The final cell suspension was disrupted by sonication or where indicated cells were left intact. Sonicated or intact cell suspensions and original supernatant fractions were assayed immediately for DAO activity, which is otherwise destroyed by freezing and thawing, by measurement of tritium release from $\left[\beta-{ }^{3} \mathrm{H}\right]$ histamine (27). Values for kinetics of binding were based on activity recovered from pellets and medium. Loss of enzyme activity (36 $\pm 9 \%$; mean \pm SEM of five preparations) occurred when low $(<20 \mathrm{U} / \mathrm{ml})$ but not high $(>50 \mathrm{U} / \mathrm{ml})$ concentrations of DAO activity were incubated at $37^{\circ} \mathrm{C}$ for $30 \mathrm{~min}$ in the absence or presence of endothelial cells. For this reason, DAO activity was assayed in both the supernatant and cellular fractions to monitor for loss of enzyme activity.

Binding of ${ }^{125} \mathrm{I}$-LPL was determined by the same procedure except that incubations were done at $22^{\circ} \mathrm{C}$ and $0.1 \% \mathrm{wt} / \mathrm{vol}$ bovine serum albumin was added to the supplemented DME. Incubations contained $5 \mathrm{ng}$ of ${ }^{125} \mathrm{I}-\mathrm{LPL}$ and sufficient unlabeled LPL to yield the indicated concentrations in a volume of $100 \mu \mathrm{l}$. Cell pellets were washed twice (and transferred to clean tubes) before assay of ${ }^{125}$ I by gamma counting or LPL catalytic activity. Initial experiments showed that values for bound ${ }^{125}$ I (disintegrations per minute per microgram of pellet protein) remained unchanged after two washes. LPL catalytic activity was determined as soon as samples were obtained by previously described procedures (25): the substrate was Intralipid (AB Vitrum, Stockholm, Sweden) that contained $\left[{ }^{3} \mathrm{H}\right]$ oleic acid-labeled trioleoylglycerol. Rat serum was used as a source of activator protein. Precautions were taken to monitor for loss (adsorption to surfaces, precipitation, or degradation) of LPL during experiments. Routinely, dialyzed and diluted enzyme preparations, medium, washings, as well as cell pellets were assayed for ${ }^{125}$ I and where indicated lipase activity. Tubes with medium and LPL alone were included in each experiment. All reagents were kept on ice. Dialyzed enzyme preparations were used within 30 min: $96-98 \%$ of ${ }^{125}$ I-LPL was precipitated with $10 \%$ trichloroacetic acid (bovine serum albumin was added as carrier) and $<5 \%$ of this was degraded to trichloracetic acid-soluble material during incubation with the cell preparations. Generally, ${ }^{125}$ I-LPL and LPL catalytic activity recovered from cell pellets and medium was $90-100 \%$ of that recovered from medium incubated without cells. Because of nonspecific binding of LPL (up to $40 \%$ with LPL concentrations $<1 \mu \mathrm{g} / \mathrm{ml}$ ) to plastic ware, binding was calculated on the basis of actual LPL recovered from medium and cell pellet.

Displacement of bound DAO activity or ${ }^{125}$ I-LPL. Endothelial cell preparations (1 mg in wet weight) were incubated with LPL or DAO activity (total volume, $100 \mu \mathrm{l}$ ) for $30 \mathrm{~min}$ as described in the previous section. The cells were recovered and washed once with $100 \mu \mathrm{l}$ of supplemented DME and resuspended in $50 \mu \mathrm{l}$ of the DME. For these steps cell suspensions were centrifuged at $500 \mathrm{~g}$ for $3 \mathrm{~min}$. Heparin, DAO, or LPL preparation was added in the amounts indicated and the volume of suspension was adjusted to $100 \mu \mathrm{l}$ with medium. The mixtures were then incubated $\left(37^{\circ} \mathrm{C}\right.$ for DAO studies, $22^{\circ} \mathrm{C}$ for $\mathrm{LPL}$ studies) for $30 \mathrm{~min}$ or as indicated. The cell fraction (after two washes) and medium were collected and assayed for DAO activity or ${ }^{125} \mathrm{I}$ as described above.

Treatment of endothelial cells with proteolytic and glycosaminoglycan-degrading enzymes. Isolated endothelial cell preparations $(1 \mathrm{mg}$ in wet weight) from rat fat pads were incubated $\left(37^{\circ} \mathrm{C}\right)$ in the absence or presence of various concentrations of the indicated enzyme preparation for 5 or $3 \mathrm{~min}$ in $0.5 \mathrm{ml}$ of DME. Ice-cold medium $(1 \mathrm{ml})$ was then added to quench the reaction and the tubes were immediately centrifuged ( $500 \mathrm{~g}$ for $3 \mathrm{~min}$ ). The cell pellet was recovered, washed once with DME, and resuspended in $0.1 \mathrm{ml}$ of DME which contained $500 \mathrm{U}$ of DAO activity/ml. The cell suspension was incubated $\left(37^{\circ} \mathrm{C}\right)$ for $30 \mathrm{~min}$ and the amount of bound DAO activity was determined as described in previous paragraphs.

Expression of enzyme activities and experimental results. $1 \mathrm{U}$ of DAO activity is equivalent to 1 pmol of histamine deaminated/h in the presence of $10^{-7} \mathrm{M}$ histamine (27). In studies of kinetics of DAO binding, a mol wt of 97,000 and purity of $85 \%$ (see subsection Enzyme preparations and extracts) was assumed. $1 \mathrm{U}$ of LPL activity is defined as $1 \mu \mathrm{mol}$ of fatty acid released $/ \mathrm{min}$ at $22^{\circ} \mathrm{C}$. Previous studies have indicated that LPL catalytic activity (or the ability of LPL to bind to heparin or to be cleared from plasma upon injection into rats) is not measurably reduced by iodination (25). Values are expressed as mean or mean \pm SEM for the number $(n)$ of experiments (i.e., different cell preparations) or determinations (same cell preparation) indicated. Tests for statistical significance were by the two-tailed $t$ test. Curve fitting of data was done through the MLAB program (28). For data shown in Fig. 6, curve fitting for one or the sum of two or three MichaelisMenten components was tested. Inasmuch as the data did not allow discrimination between fit of two or three components, calculations were based on an assumed two-component system.

\section{Results}

DAO binding: preliminary studies with placental extracts. Both the rat and guinea pig microvascular cell preparations bound DAO activity present in rat and human placental preparations (Table I). In the presence of low DAO activity and $1 \mathrm{mg}$ of endothelial cell preparation the percentage of DAO activity bound ranged from $16.4 \pm 1.2(n=6$, with $20 \mathrm{DAO} \mathrm{U} / \mathrm{ml})$ to $28 \pm 4.2(n=3,1 \mathrm{DAO} \mathrm{U} / \mathrm{ml})$. Repeated washing of the cells with $100 \mu \mathrm{l}$ of ice-cold medium removed $<10 \%$ of the bound DAO activity at each wash. Most of this loss was attributable to incomplete recovery or breakage of cells because there was a similar loss of cell protein. Binding was apparent at $4^{\circ} \mathrm{C}$ and $37^{\circ} \mathrm{C}$ and at both temperatures equilibrium was reached by 5-15 min. Subsequently, there was some decrease in the amount of bound activity at $37^{\circ} \mathrm{C}$ not at $4^{\circ} \mathrm{C}$ (Fig. 2). Although some of this decrease may have been due to inactivation of DAO activity (see Methods) small decreases were still evident when bound DAO activity was expressed as the percentage of total activity recovered from cells and medium. Binding was observed with microvessel preparations obtained from fat pads of two strains of rats as well as guinea pigs (Fig. 3 ). The enzyme activity bound was related to concentration of enzyme activity (Fig. $3 \mathrm{~A}$ ) and amount of tissue (Fig. $3 \mathrm{~B}$ and $C$ ). Saturation of binding was not achieved in the presence

Table I. Binding of DAO Activity to Microvascular Endothelial Cell Preparations from Fat Pads of Rat and Guinea Pig

\begin{tabular}{llll}
\hline & & \multicolumn{2}{l}{ DAO activity bound } \\
\cline { 3 - 4 } Source of DAO & Activity & Rat & Guinea pig \\
\hline $\begin{array}{l}U / \mu g \text { of } \\
\text { protein }\end{array}$ & $\begin{array}{l}U / m g \text { of } \\
\text { tissue }\end{array}$ & $\begin{array}{l}U / m g \text { of } \\
\text { tissue }\end{array}$ \\
$\begin{array}{l}\text { Rat placenta } \\
\text { Extract }\end{array}$ & $0.48 \pm 0.06$ & $2.30 \pm 0.47$ & $3.36 \pm 0.84$ \\
$\begin{array}{l}\text { Purified enzyme } \\
\text { Human placenta }\end{array}$ & 94 & $2.38 \pm 0.22$ & - \\
Extract & $0.28 \pm 0.08$ & $1.30 \pm 0.36$ & - \\
\end{tabular}

Microvascular endothelial cells were incubated with DAO preparations (300 U/ $\mathrm{ml}$ ) in $100 \mu \mathrm{l}$ of DME for $60 \mathrm{~min}$ at $37^{\circ} \mathrm{C}$. Bound DAO activity was determined as described in Methods. Values are mean \pm SEM of three to four experiments. 


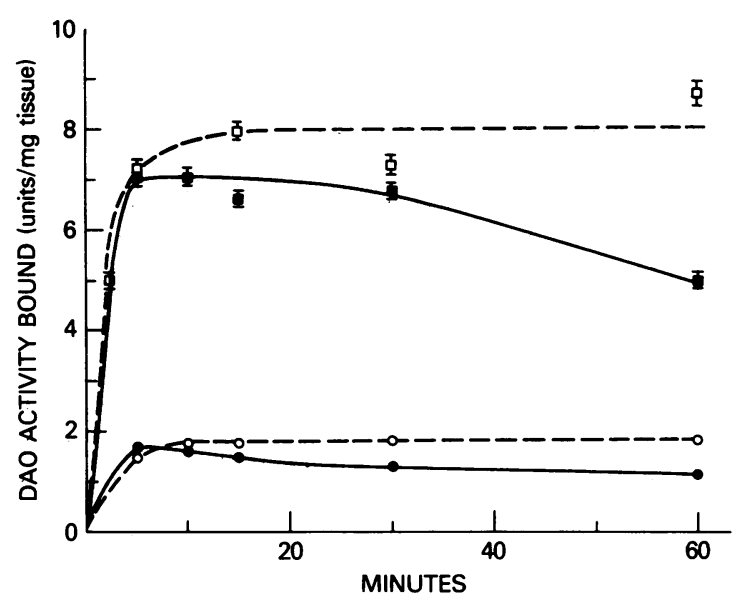

Figure 2. Time course of binding of DAO activity from rat placental extracts to isolated rat fat pad microvascular endothelial cells. Cell preparations were incubated at $37^{\circ} \mathrm{C}(\bullet, \square)$ and $4^{\circ} \mathrm{C}(0, \square)$ with rat placental extracts (60 DAO U/ml [०, o] and $600 \mathrm{U} / \mathrm{ml}[\mathrm{n}$, 미) for 0$60 \mathrm{~min}$ in a volume of $100 \mu \mathrm{l}$. The mixture was centrifuged; medium and cell pellets were assayed for DAO activity as described in Methods. Values are expressed as units of DAO activity recovered from the cell pellets and are mean of two determinations or mean \pm SEM of three determinations and are from one of two similar experiments.

of up to $1,000 \mathrm{U}$ of DAO activity/ml of medium (a representațive experiment is shown in Fig. $3 \mathrm{~A}$ ). At this level of enzyme activity cell pellets for all experiments $(n=4)$ contained 7.7 \pm 1.6 DAO $\mathrm{U} / \mathrm{mg}$ of tissue $(0.31 \pm 0.07 \mathrm{U} / \mu \mathrm{g}$ of protein).

Binding did not appear to interfere with the catalytic activity of enzyme. DAO activity as measured in intact cells was not significantly different from that in sonicated rat endothelial cell suspensions. ${ }^{3}$ All of the DAO activity (104 $\pm 7 \%$ of activity added; $n=9$ ) could be recovered from intact cell pellet and medium in incubations containing $>50$ DAO U/ml.

Displacement of DAO activity by heparin. With cell preparations previously treated with placental extracts, bound DAO activity was released rapidly into the medium in the presence of $40 \mu \mathrm{g}$ of heparin/ml $(5 \mathrm{U} / \mathrm{ml}$ ) (Fig. $4 A$ ). Release was observed with as little as $0.2-0.4 \mu \mathrm{g}$ of heparin $/ \mathrm{ml}(0.025-0.05$ $\mathrm{U} / \mathrm{ml}$ ) and near-maximal release was observed with $8 \mu \mathrm{g}$ of heparin/ml (Fig. 4 B).

Kinetics of binding of $D A O$ activity: studies with purified placental enzyme preparations. With purified preparations of enzyme DAO binding occurred at $37^{\circ} \mathrm{C}$ and at a slightly slower rate at $4^{\circ} \mathrm{C}$. Binding was near-maximal by $30 \mathrm{~min}$ (Fig. 5). Saturation of binding was approached with levels of activity above $5,000 \mathrm{U}$ of DAO activity/ml to yield cell pellets containing $0.46-0.62 \mathrm{DAO} \mathrm{U} / \mu \mathrm{g}$ of tissue protein $(\sim 11-13 \mathrm{U} / \mathrm{mg}$ of tissue). Scatchard plot of the data (Fig. 6) was consistent with binding to at least two classes of sites, one of which had a high affinity for DAO with a dissociation constant $K_{1}$ of $92 \pm 51 \mathrm{U} / \mathrm{ml}(\sim 9 \mathrm{nM})$ and a value for maximum binding $\left(n_{1}\right)$ of $0.08 \pm 0.02 \mathrm{U}(\sim 0.75 \mathrm{ng}$ of $\mathrm{DAO}) / \mu \mathrm{g}$ of cell protein. These values should be considered as approximate estimates, in view of the fact that data were obtained from five experiments to

3. With two preparations of cells exposed to 20 and $150 \mathrm{DAO} \mathrm{u} / \mathrm{ml}$, activities in intact cell suspensions were respectively $75 \%(n=8)$ and $82 \%(n=4)$ of that in sonicated cell suspensions $(P>0.2)$.
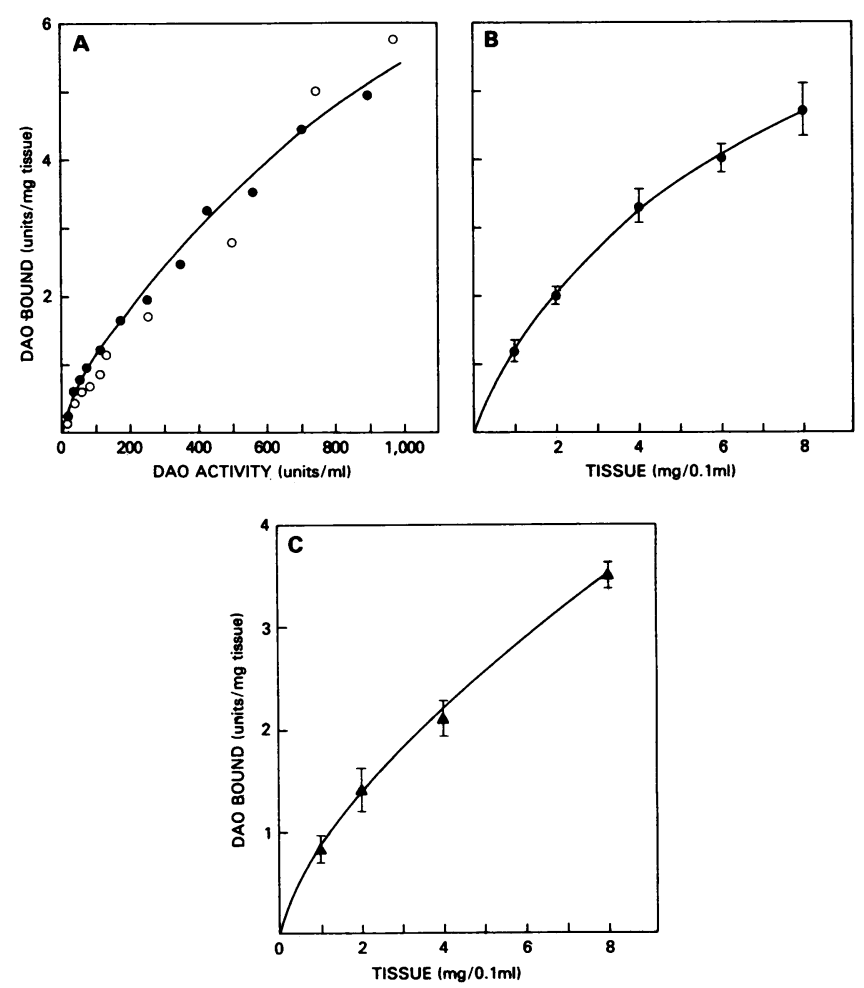

Figure 3. Binding of DAO activity from rat placental extracts to fat pad microvascular endothelial cell preparations from rat $(A$ and $B)$ and guinea pig $(C)$ in relation to amount of DAO activity $(A)$ or of tissue $(B$ and $C$ ) present. Cell preparations were incubated $(30 \mathrm{~min}$ at $37^{\circ} \mathrm{C}$ ) with placental extract in a total volume of $100 \mu$ l. Bound DAO activity was determined as described in Methods. In $A$, preparations of cells from Sprague-Dawley ( $\bullet$ ) and Osborne-Mandel (O) rats were tested and DAO activity was varied as indicated; the weight of cell preparation was held constant ( $1 \mathrm{mg}$ of wet tissue, $20 \mu \mathrm{g}$ of protein). Values are mean of duplicate determinations. In $B$, DAO activity present was $200 \mathrm{U} / \mathrm{ml}$ and cell preparation contained $29 \mu \mathrm{g}$ of protein $/ \mathrm{mg}$ of wet pellet. Values are mean \pm SEM of three determinations. In $C$, DAO activity was $100 \mathrm{U} / \mathrm{ml}$ and three cell preparations from guinea pigs were tested (average protein content $40 \mu \mathrm{g} / \mathrm{mg}$ of tissue). Values are mean \pm SEM from the three preparations.

obtain a sufficient number of points (see legend to Fig. 6). The calculated values for an assumed low-affinity site were $K_{2}$, $2,450 \pm 175 \mathrm{U} / \mathrm{ml}(250 \mathrm{nM})$ and $n_{2} 0.62 \pm 0.03 \mathrm{U}(\sim 6.2 \mathrm{ng}$ of $\mathrm{DAO}) / \mu \mathrm{g}$ of cell protein. The studies further suggested that DAO kinetics of binding were similar for both the extract and purified enzyme (Fig. 6) despite differences in the time course of binding with each preparation (e.g., Fig. 2 vs. Fig. 5). Studies with the purified enzyme also indicated that after exposure of cells to both low and high DAO concentrations, bound activity could be displaced by heparin at $40 \mu \mathrm{g} / \mathrm{ml}$. At DAO concentrations of $50 \mathrm{U} / \mathrm{ml}, 76 \pm 2 \%$ of the DAO activity bound was displaced by heparin and at concentrations of $5,000 \mathrm{U} / \mathrm{ml}, 67 \pm 2 \%$ of the bound activity was displaced (values from four experiments).

Binding of DAO and LPL to preparations of rat fat pad microvascular endothelial cells. Freshly isolated endothelial cell preparations ( $1 \mathrm{mg}$ of tissue in $100 \mu \mathrm{l}$ ) bound $27-33 \%$ of bovine milk LPL in the presence of low enzyme concentrations $(<12 \mu \mathrm{g} / \mathrm{ml}$ ). With higher concentrations of LPL, the slope of the binding curve decreased but saturation of binding was not achieved at concentrations up to $60 \mu \mathrm{g} / \mathrm{ml}$. Higher concentra- 

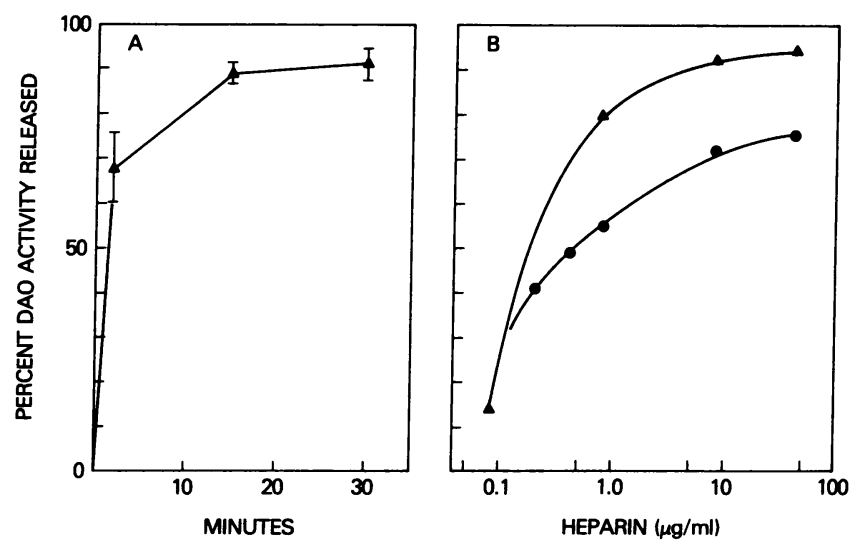

Figure 4. Displacement of bound DAO activity by heparin with time $(A)$ or with various concentrations of heparin $(B)$. Microvascular endothelial cell preparations from guinea pig $(\Delta)$ or rat $(\bullet)$ fat pads were incubated $\left(60 \mathrm{~min}\right.$ at $\left.37^{\circ} \mathrm{C}\right)$ with rat placental extracts $(75 \mathrm{U} /$ $\mathrm{ml}$ ) in a volume of $100 \mu \mathrm{l}$. The tissue was recovered, washed, and resuspended in $100 \mu \mathrm{l}$ of fresh medium; heparin was added to give a final concentration of $40 \mu \mathrm{g} / \mathrm{ml}(5 \mathrm{U} / \mathrm{ml})$ in $A$ or the indicated concentration in $B$. The suspensions were reincubated $\left(37^{\circ} \mathrm{C}\right)$ for the stated times in $A$ and for $30 \mathrm{~min}$ in $B$. Cells and medium were assayed for DAO activity. Values are mean of two or mean \pm SEM of four determinations. Values are uncorrected for spontaneous release $(10-15 \%$ in $30 \mathrm{~min})$.

tions were not tested because of indications that LPL precipitated in incubations that were run in the absence of cells. ${ }^{4}$ Although individual experiments provided reproducible data (Fig. 7), the presence of a high-affinity LPL binding site was apparent at LPL concentrations below $1 \mu \mathrm{g} / \mathrm{ml}$ in only two of seven experiments. Scatchard plots of all data (representative data are shown in Fig. 8) indicated variability between experiments, and we conclude that LPL binding sites cannot be reasonably defined under the conditions of our experiments. Nevertheless, the amounts bound at low concentrations of LPL $(1 \mu \mathrm{g} / \mathrm{ml})$ or DAO $(100 \mathrm{U}$ or $1 \mu \mathrm{g}$ of $\mathrm{DAO} / \mathrm{ml})$ were similar (0.9-1.9 $\mathrm{ng}$ of LPL and $0.5-1.0 \mathrm{ng}$ of $\mathrm{DAO} / \mu \mathrm{g}$ of cell protein). Moreover, lipase activity could be recovered from the cell pellet and incubation medium in the same proportion as the ${ }^{125} \mathrm{I}$ label. For example, in the presence of ${ }^{125} \mathrm{I}-\mathrm{LPL}$ alone, the specific activity of LPL in the medium and cell pellet was, respectively, 7,570 and 7,710 cpm/mU. Bound LPL activity (33 $\pm 2 \%$ of LPL was bound to cells, $n=3)$ was displaced by $40 \mu \mathrm{g} / \mathrm{ml}$ of heparin to the same extent irrespective of whether or not low $(0.05 \mu \mathrm{g}$ of $\mathrm{LPL} / \mathrm{ml})$ or high $(15 \mu \mathrm{g}$ of $\mathrm{LPL} / \mathrm{ml}$ ) concentrations were used (the percentage of displacement for all experiments was $53 \pm 4 \%$; range, $44-63 \%$; values from four experiments).

The presence of LPL on the endothelial cell did not affect the binding of DAO activity except when the cells were exposed previously to high (35 $\mu \mathrm{g}$ of $\mathrm{LPL} / \mathrm{ml}$ or greater) concentrations of LPL (Table II) and DAO was displaced to only a limited extent $(33 \%, P<0.05)$ by high concentrations (30 $\mu \mathrm{g} / \mathrm{ml}$ ) of LPL (see legend to Table II). Additionally, significant displacement of bound LPL was observed with only high concentrations $(5,000 \mathrm{U} / \mathrm{ml})$ of DAO activity (Table III). The data in Table III do suggest that small amounts of bound

4. In one experiment, precipitation was evident at $30 \mu \mathrm{g} / \mathrm{ml}$ of LPL.

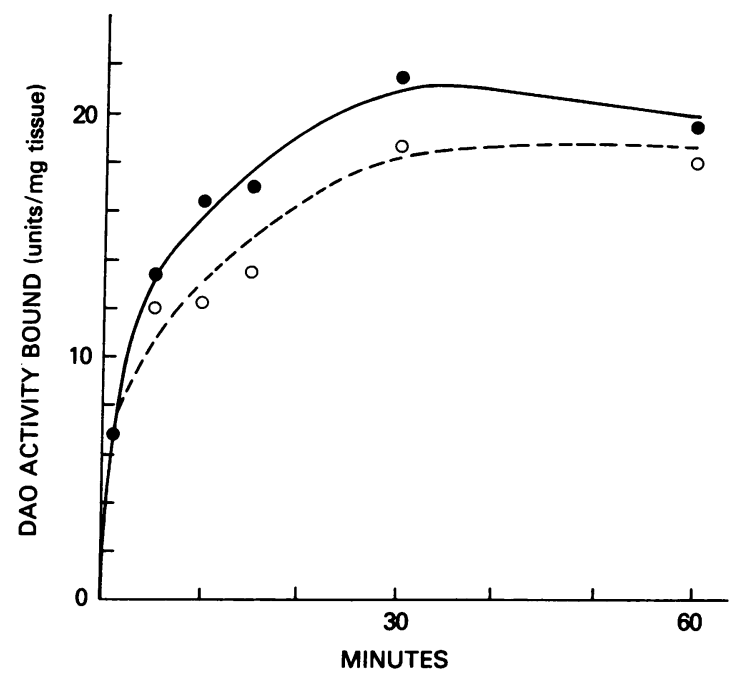

Figure 5. Time course of DAO binding: studies with purified rat placental DAO preparation. Microvascular endothelial cells from rat fat pad ( $1 \mathrm{mg}$ in wet weight, $30 \mu \mathrm{g}$ of protein) were incubated at $37^{\circ} \mathrm{C}(\bullet)$ or $4^{\circ} \mathrm{C}(0)$ with the purified DAO preparation $(1,500 \mathrm{U} / \mathrm{ml})$ in a volume of $100 \mu$ l. Bound DAO activity was determined as described in Methods. Values are mean of duplicate determinations.

LPL were more resistant to displacement by DAO than large amounts of bound LPL.

Effect of proteolytic and glycosaminoglycan-degrading enzymes on DAO binding. DAO binding was impaired by prior

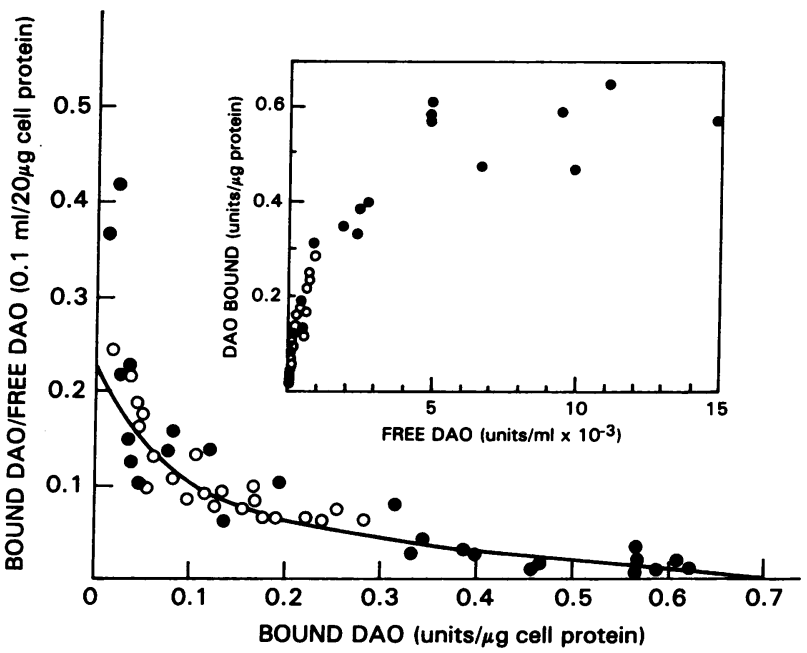

Figure 6. Scatchard plot of binding of DAO activity to microvascular endothelial cells from rat fat pad in the presence of purified DAO from rat placenta $(0)$ or extracts of rat placenta (๑). Cell preparations (1 mg in wet weight, $20 \mu \mathrm{g}$ of protein) were incubated with 10 $15,000 \mathrm{DAO} \mathrm{U} / \mathrm{ml}$ in a volume of $100 \mu \mathrm{l}$ for $30 \mathrm{~min}\left(37^{\circ} \mathrm{C}\right)$ before assay of DAO activity in cells and medium (inset). Data points are from five experiments with different cell preparations in which two preparations of purified DAO enzyme and two placental extracts were tested. Each point is the mean value of duplicate determinations. Values are expressed as units of DAO bound/microgram of cell protein. Plot of actual data (i.e., units bound/milligram of tissue) indicated maximum binding in the range of $9-13 \mathrm{U} / \mathrm{mg}$ of tissue (eight points) with most values falling between 11-13 U/mg of tissue (six points). Computer simulation of data in the inset to fit sum of two Michaelis-Menten components is shown by the solid line (see text for calculated kinetic parameters). 


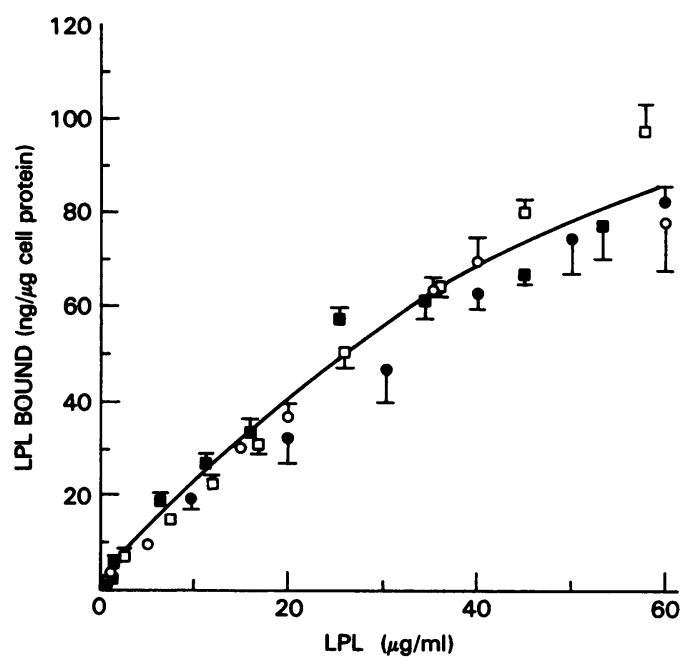

Figure 7. Binding of ${ }^{125} \mathrm{I}-\mathrm{LPL}$ to rat fat pad microvascular endothelial cells in relation to LPL concentration. Data from four separate experiments are shown by different symbols and are representative of seven experiments. Data points and bars are mean \pm SEM of three to four determinations (bars omifted where these fall within data points). Cell preparations, $1 \mathrm{mg}$ (13-15 $\mu \mathrm{g}$ of protein), were incubated $\left(30 \mathrm{~min}\right.$ at $22^{\circ} \mathrm{C}$ ) with ${ }^{125} \mathrm{I}-\mathrm{LPL}(5 \mathrm{ng})$ and sufficient unlabeled LPL to yield the indicated concentration. Cells were recovered and washed twice for assay of bound ${ }^{125}$ I. See Methods for additional details. The time course of LPL binding (data not shown) was similar to that of DAO activity (Fig. 4) with maximum binding by $30 \mathrm{~min}$.

digestion $\left(37^{\circ} \mathrm{C}\right.$ for $\left.5 \mathrm{~min}\right)$ of endothelial cells with several enzyme preparations. After incubation of the cells with 6, 12, 60 , and $120 \mathrm{mIU} / \mathrm{ml}$ heparinase, DAO binding was reduced by, respectively, $26 \pm 4,55 \pm 3,59 \pm 3$ and $68 \pm 3 \%$. Similar treatment with Pronase (1 PUK unit/ml) or trypsin $(0.05 \%)$ resulted in $57 \pm 8 \%$ and $60 \pm 7 \%$ loss of DAO binding activity (values are mean $\pm \operatorname{SEM}, n=4)$. In another experiment, treatment with trypsin $(0.05 \%$ for $3 \mathrm{~min})$ resulted in equal reduction of DAO and LPL binding; $53 \%$ vs. $47 \%$, respectively. None of these treatments caused loss of cell viability ( $>95 \%$ of cells remained viable). Substantial loss of DAO binding activity

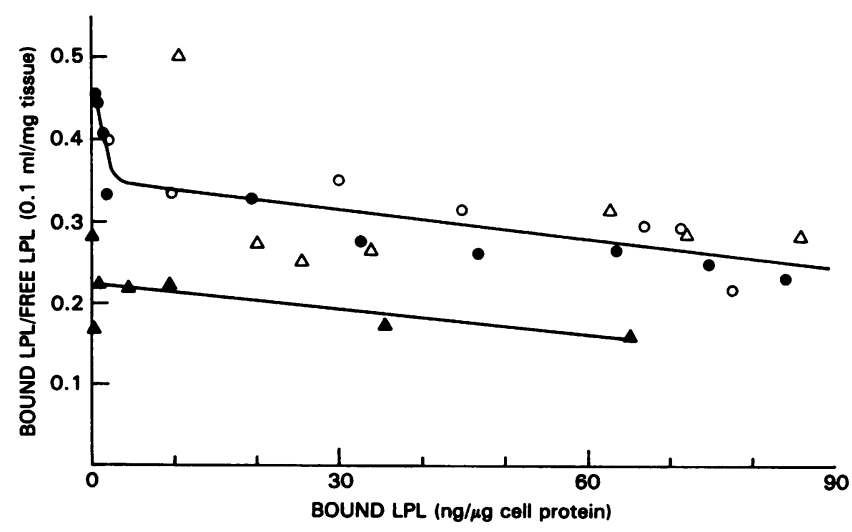

Figure 8. Scatchard plots of four experiments of LPL binding to rat endothelial cell preparations. Two experiments $(\bullet, 0)$ are from experiments shown in Fig. 7 and two $(\Delta, 15 \mu \mathrm{g}$ of protein; $\Delta, 24 \mu \mathrm{g}$ of protein) are additional experiments. Experimental details and symbols are as described in the legend to Fig. 7. The experiments were selected from seven experiments and were chosen to indicate scatter and variability of data points.
Table II. Binding of DAO Activity to Microvascular

Endothelial Cells Previously Exposed to LPL*

\begin{tabular}{cllll}
\hline \multicolumn{5}{c}{ DAO activity } \\
\cline { 2 - 5 } & $100 \mathrm{U} / \mathrm{ml}$ & $500 \mathrm{U} / \mathrm{ml}$ & $1,000 \mathrm{U} / \mathrm{ml}$ & $5,000 \mathrm{U} / \mathrm{ml}$ \\
\hline$\mu g / \mathrm{ml}$ & \multicolumn{4}{l}{ of $D A O$ bound $/ \mu \mathrm{g}$ of protein } \\
0 & $0.03 \pm 0.01$ & $0.20 \pm 0.01$ & $0.33 \pm 0.01$ & $1.04 \pm 0.07$ \\
1 & $0.06 \pm 0.01$ & - & $0.36 \pm 0.03$ & $1.03 \pm 0.03$ \\
20 & - & - & - & $1.18 \pm 0.01$ \\
35 & - & - & - & $0.76 \pm 0.03 \ddagger$ \\
40 & - & - & - & $0.62 \pm 0.02 \S$ \\
60 & - & - & - & $0.58 \pm 0.07 \S$
\end{tabular}

* Values are mean \pm SEM of four incubations. Preparations of isolated rat fat pad microvascular endothelial cells (1 mg in wet weight, $23 \mu \mathrm{g}$ of protein) were first incubated $\left(30 \mathrm{~min}\right.$ at $\left.22^{\circ} \mathrm{C}\right)$ with the indicated concentrations of LPL, washed, and then incubated $\left(30 \mathrm{~min}\right.$ at $\left.37^{\circ} \mathrm{C}\right)$ with the indicated concentration of purified preparation of DAO before assay of bound DAO activity as described in Methods. Final incubation volumes were $100 \mu \mathrm{l}$. In a second experiment (1 mg of cell preparation, $21 \mu \mathrm{g}$ of protein) in which the sequence of incubations was reversed (5,000 DAO U/ml and then LPL) the following DAO activities (in units per microgram of protein) were recovered from the cell pellets: $0.78 \pm 0.06(0), 0.79 \pm 0.10(2.5), 0.64 \pm 0.16(12.5)$, and $0.52 \pm 0.04(30)$. Values in parentheses indicate micrograms of LPL per milliliter in the second incubation mixture.

¥ Significant difference from control values, $P<0.05$.

$\S$ Significant difference from control values, $P<0.005$.

(70-85\%) occurred after incubation $(5 \mathrm{~min})$ of cells with 10 PUK units/ml of Pronase but this treatment also led to considerable loss (up to $60 \%$ ) of cell viability. These data suggested that DAO (and LPL) activity was bound to superficial sites on the cell surface that were readily destroyed by enzymatic treatment.

\section{Discussion}

Several macromolecular substances, which include lipoprotein lipase $(18,19)$, angiotensin-converting enzyme (29), $\alpha$-macro-

Table III. Displacement of Bound ${ }^{125}$ I-LPL by DAO on Microvascular Endothelial Cells*

\begin{tabular}{|c|c|c|c|c|}
\hline \multirow{2}{*}{$\begin{array}{l}\text { Initial LPL } \\
\text { concentration }\end{array}$} & \multicolumn{2}{|l|}{ LPL bound } & \multirow{2}{*}{$\begin{array}{l}\text { LPL } \\
\text { displaced }\end{array}$} & \multirow[b]{2}{*}{$P \neq$} \\
\hline & -DAO & +DAO & & \\
\hline$\mu g / m l$ & $\begin{array}{l}\text { ng/ug of } \\
\text { protein }\end{array}$ & $\begin{array}{l}\text { ng/ug of } \\
\text { protein }\end{array}$ & $\%$ & \\
\hline 0.025 & $0.025 \pm 0.001$ & $0.024 \pm 0.002$ & - & - \\
\hline 0.050 & $0.072 \pm 0.002$ & $0.061 \pm 0.004$ & 15 & - \\
\hline 0.075 & $0.100 \pm 0.002$ & $0.079 \pm 0.010$ & 21 & - \\
\hline 1.0 & $1.80 \pm 0.12$ & $1.21 \pm 0.04 \S$ & 33 & $<0.01$ \\
\hline 40.0 & $70 \pm 5$ & $30 \pm 2$ & 57 & $<0.005$ \\
\hline 60.0 & $77 \pm 14$ & $51 \pm 2$ & $34^{\prime \prime}$ & - \\
\hline
\end{tabular}

* Data are mean \pm SEM of three determinations. Isolated rat fat pad microvascular endothelial cell preparations (1 mg in wet weight, $24 \mu \mathrm{g}$ of protein) were first incubated $\left(22^{\circ} \mathrm{C}\right.$ for $\left.30 \mathrm{~min}\right)$ with the indicated concentrations of LPL and ${ }^{125} \mathrm{I}-\mathrm{LPL}$, washed, and then incubated $\left(37^{\circ} \mathrm{C}\right.$ for $\left.30 \mathrm{~min}\right)$ in the absence or presence of purified DAO preparation $(5,000 \mathrm{U} / \mathrm{ml})$ before assay of bound ${ }^{125} \mathrm{I}-\mathrm{LPL}$ as described in Methods. Final volumes of all incubation mixtures were $100 \mu \mathrm{l}$. ¥ Significant difference from samples incubated without DAO at the indicated $P$ value.

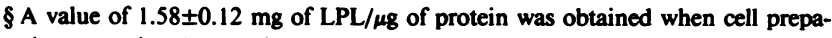
rations were incubated with $1,000 \mathrm{U}$ of $\mathrm{DAO} / \mathrm{ml}$ (12\% displacement).

"A second experiment showed 33\% displacement $(P<0.02)$ of LPL by DAO. 
globulin (30), and Factors VIII $(31,32)$, IX, and X (33), are located close to or at the endothelial cell surface. Some of these substances are synthesized within the cell but others, lipoprotein lipase in particular, are produced by cells other than endothelial cells and then bind to the endothelial cell surface (for recent reviews, see reference 34). Lipoprotein lipase, whose normal site of action is at the capillary endothelium in extrahepatic tissues (20), is thought to attach to heparan sulfate or similar material $(18-20,35,36)$ present on the endothelial membrane surface (37). The attached lipoprotein lipase is readily displaced by heparin or dextran sulfate. Kinetic binding studies with endothelial cell cultures $(18,19)$ indicate that the enzyme binds to a high-affinity site with an association constant of $K=70 \mathrm{nM}$ and a maximal binding $(n)$ of $0.84 \mu \mathrm{g}$ of LPL/10 $10^{6}$ cells although the presence of a low-affinity site ( $K$ $=100 \mu \mathrm{M}, n=18.4 \mu \mathrm{g}$ of $\mathrm{LPL} / 10^{6}$ cells) was observed in one experiment (19). The ability of vascular endothelial cells to bind enzymes may thus provide a simple mechanism for metabolizing substrates in the circulating blood. The present studies suggest that in addition to lipoprotein lipase, endothelial cells are capable of concentrating very high DAO activity on their surface.

DAO binding appears to be due to the presence of both high-affinity and low-affinity sites for the enzyme. Based on the assumptions made (see Methods), we calculate values of 9 and $250 \mathrm{nM}$ for $K_{1}$ and $K_{2}$, maximum binding of 0.06 and $0.5 \mu \mathrm{g}$ of $\mathrm{DAO} / 10^{6}$ cells for these two sites, and $\sim 4 \times 10^{5}$ high-affinity binding sites per cell. The ability to bind DAO from placental extracts also suggest that tissue constituents do not impede binding. The DAO binding sites have several features in common with LPL binding sites with respect to displacement of enzyme with heparin, and relatively large number of binding sites on each cell. Because LPL did not interfere with or displace DAO activity except to only a limited extent at high LPL concentrations, LPL and high-affinity DAO binding sites may be distinct entities. If this is so and heparan sulfate or related sulfated glycosaminoglycans are responsible for binding of both enzymes, the characteristics of the binding sites must be such that they permit selective affinities for each of the two enzymes. At high concentrations of DAO, however, the data point to possible binding of DAO and LPL to a common site.

The impairment of DAO binding by prior treatment of cells with proteolytic and glycosaminoglycan-degrading enzymes suggests that DAO activity is bound to superficial sites on the cell surface. The contaminants in the heparinase preparation (see Methods) do not allow definitive identification of the nature of the binding site.

The maintenance of DAO activity, as for LPL activity (18, 19,38 ), when the enzyme is bound to the endothelial cell surface indicates that binding does not interfere with or occlude the enzyme catalytic site. To account for the retention of LPL activity, a model has been proposed for the LPL receptor in which heparan sulfate is complexed with protein in the membrane lipid bilayer. A sufficient length of free polysaccharide chain is available to allow binding of enzyme away from the membrane surface (20).

It was important to characterize DAO binding in freshly isolated microvascular endothelial cells inasmuch as the presence of high DAO activities in calf or horse serum (unpublished data) creates practical problems in studies with cultured endothelial cells. The use of freshly isolated cells, however, imposes certain constraints. The procedures are time-consuming and yield relatively small amounts of material, which consists of single and multiple cell segments. This limits the number of data points that can be obtained in one experiment and does not allow cell numbers to be defined precisely. There is also uncertainty as to the contribution of other cell types which, in our hands, account for $8-19 \%$ of the total cells present. Nevertheless, the general characteristics of DAO binding proved to be reproducible from preparation to preparation, with respect to the maximum capacity of the cells to bind DAO, displacement by heparin, and kinetics of binding. The values obtained when cells were saturated with DAO were higher than the DAO activity observed in all tissues except placenta (see data in reference 27), and because DAO, unlike LPL, does not stick to hydrophobic surfaces (as was observed consistently in this and previous studies), we doubt that DAO binding was artifactual. The values for kinetic constants, however, should be regarded as approximate in view of the heterogenous nature of the cell preparations.

If endothelial cells do, indeed, bind DAO in the intact animal, the DAO could serve useful functions under these conditions. The major substrates of DAO, histamine and putrescine, are biologically active. Small increases in plasma histamine, for example, produce marked changes in cardiovascular functions and larger increases result in anaphylactic shock (39). Histamine does not readily penetrate into cells, but it is largely metabolized upon a single passage across most vascular beds (39). Degradation of histamine at extracellular sites on the endothelial cell would provide an efficient mechanism for clearing histamine from the circulation. Putrescine and related polyamines are produced in tissues undergoing rapid growth or cell division and the uniquely high DAO activity in placenta (40), intestinal mucosa $(41,42)$, and thymus stroma (43) is thought to be associated with the high production of these amines in fetus, intestinal mucosal cells, and thymocytes. In the intestine, DAO is synthesized in the villus cells but then appears to be transported to heparinsensitive binding sites. Although these sites were not identified the intestinal vasculature was suggested as one possible location (41). At such a location DAO may serve a protective function in preventing leakage of amines from the intestine into the circulation. As the present studies demonstrate after binding of DAO or LPL to endothelial cells, catalytic activities are not impaired or rapidly destroyed.

\section{Acknowledgments}

We thank Dr. Hiroka Satoh for assistance in the disk gel electrophoresis experiment with DAO and John W. George for assistance with the MLAB program and computer simulation.

This work was supported in part by the Swedish Medical Research Council (13X-727).

\section{References}

1. Zeller, E. A. 1965. Identity of histaminase and diamine oxidase. Fed. Proc. 24:766-768.

2. Buffoni, F. 1966. Histaminase and related amine oxidases. Pharmacol. Rev. 18:1163-1199.

3. Schayer, R. W. 1956. The metabolism of histamine in various species. Br. J. Pharmacol. Chemother. 11:472-473.

4. Schayer, R. W. 1966. Catabolism of histamine in vivo. In Handbook of Experimental Pharmacology. M. Rocha e Silva, editor. Vol. XVIII/part 1. Springer-Verlag, New York. 672-683. 
5. Swanberg, H. 1948. Source of histaminolytic enzyme in blood of pregnant women. Acta Physiol. Scand. 16:83-96.

6. Southren, A. L., A. M. Calanog, S. Mishr, and A. B. Weingold. 1970. Effect of cycloheximide on production of diamine oxidase by the human placenta. J. Appl. Physiol. 29:684-686.

7. Ahlmark, A. 1944. Studies on the histaminolytic power of plasma with special reference to pregnancy. Acta Physiol. Scand. 9 (Suppl. 28):1-107.

8. Tryding, N., and B. Willert. 1968. Determination of plasma diamine oxidase (histaminase) in clinical practice. J. Clin. Lab. Invest. 22:29-32.

9. Hansson, R., N. Tryding, and A. Tornquist. 1969. Diamine oxidase (histaminase) in human pregnancy. Acta Obstet. Gynecol. Scand. 48:8-18.

10. Southren, A. L., A. B. Weingold, Y. Kobayashi, D. H. Sherman, R. Grimaldi, and E. M. Gold. 1968. Plasma diamine oxidase in pregnancy complicated by diabetes mellitus. Am. J. Obstet. Gynecol. 101:899-908.

11. Beaven, M. A., J. R. Marshall, S. B. Baylin, and A. Sjoerdsma. 1975. Changes in plasma histaminase activity during normal early human pregnancy and pregnancy disorders. Am. J. Obstet. Gynecol. 123:605-609.

12. Hansson, R., S. Holmberg, S. Tibbling, N. Tryding, H. Westling, and $\mathrm{H}$. Wetterquist. 1956. Heparin-induced diamine oxidase increase in human blood plasma. Acta Med. Scand. 180:533-536.

13. Dahlback, O., R. Hansson, S. Tibbling, and N. Tryding. 1968. The effect of heparin on diamine oxidase and lipoprotein lipase in human lymph and blood plasma. Scand. J. Clin. Lab. Invest. 21:1725.

14. Baylin, S. B., M. A. Beaven, R. M. Krauss, and H. R. Keiser. 1973. Response of plasma histaminase activity to small doses of heparin in normal subjects and patients with hyperlipoproteinemia. $J$. Clin. Invest. 52:1985-1993.

15. Hansson, R., and H. Thysell. 1971. Heparin-induced increase of diamine oxidase in lymph and blood plasma of rat, guinea pig and rabbit. Acta Physiol. Scand. 81:208-214.

16. Giertz, H., and F. Hahn. 1969. Mechanism of histaminase liberation in guinea pig anaphylaxis. Int. Arch. Allergy Appl. Immunol. 36:41-44.

17. Robinson-White, A., and M. A. Beaven. 1983. Presence of histamine and histamine metabolizing enzymes in rat and guinea pig microvascular endothelial cells. J. Pharmacol. Exp. Ther. 223:440445.

18. Shimada, K., P. J. Gill, J. E. Silbert, W. H. J. Douglas, and B. L. Fanburg. 1981. Involvement of cell surface heparin sulfate in the binding of lipoprotein lipase to cultured bovine endothelial cells. $J$. Clin. Invest. 68:995-1002.

19. Cheng, C.-F., G. M. Oosata, A. Bensadoun, and R. D. Rosenberg. 1981. Binding of lipoprotein lipase to endothelial cells in culture. J. Biol. Chem. 256:12893-12898.

20. Olivecrona, T., G. Bengtsson, S.-E. Markland, U. Lindahl, and M. Hook. 1977. Heparin-lipoprotein lipase interactions. Fed. Proc. 36: 60-65.

21. Baylin, S. B., and S. Margolis. 1975. Purification of histaminase (diamine oxidase) from human pregnancy plasma by affinity chromatography. Biochim. Biophys. Acta. 397:294-306.

22. Baylin, S. B. 1977. Histaminase (diamine oxidase) activity in human tumors: an expression of a mature genome. Proc. Natl. Acad. Sci. USA. 74:883-887.

23. Bengtsson, G., and T. Olivecrona. 1977. Interaction of lipoprotein lipase with heparin-Sepharose. Biochem. J. 167:109-119.
24. Bengtsson, G., and T. Olivecrona. 1980. Lipoprotein lipase: some effects of activator proteins. Eur. J. Biochem. 106:549-555.

25. Wallinder, L., J. Peterson, T. Olivecrona, and G. BengtssonOlivecrona. 1984. Hepatic and extrahepatic uptake of intravenously injected lipoprotein lipase. Biochim. Biophys. Acta. 795:513-524.

26. Lionetti, F. J., S. M. Hunt, P. S. Lin, S. R. Kurtz, and C. R. Valeri. 1977. Preservation of human granulocytes. II. Characteristics of granulocytes obtained by counterflow centrifugation. Transfusion (Phila.). 17:465-472.

27. Beaven, M. A., and R. E. Shaff. 1975. Study of the relationship of histaminase and diamine oxidase activities in various rat tissues and plasma by sensitive isotopic assay procedures. Biochem. Pharmacol. 24:979-984.

28. Knott, G. D. 1979. MLAB—a mathematical modeling tool. Comput. Programs Biomed. 10:271-280.

29. Ryan, U. S., J. W. Ryan, C. Whitaker, and A. Chiu. 1976. Localization of angiotensin converting enzyme (kininase II). II. Immunocytochemistry and immunofluorescence. Tissue Cell. 8:125-146.

30. Becker, C. G., and P. C. Harpel. 1976. $\alpha_{2}$-Macroglobulin on human vascular endothelium. J. Exp. Med. 144:1-9.

31. Jaffee, E. A., D. W. Hoyer, and R. L. Nachman. 1973. Synthesis of antihemophilic factor antigen by cultured human endothelial cells. J. Clin. Invest. 52:2757-2764.

32. Hoyer, L. W., R. P. De Los Santos, and J. R. Hoyer. 1973. Antihemophilic factor antigen. Localization in endothelial cells by immunofluorescent microscopy. J. Clin. Invest. 52:2737-2744.

33. Heimark, R. L., and S. M. Schwartz. 1983. Binding of coagulation factors IX and X to the endothelial cell surface. Biochem. Biophys. Res. Commun. 111:723-731.

34. Fishman, A. P., editor. 1982. Endothelium. Ann. NY Acad. Sci. 401:1-170.

35. Olivecrona, T., and G. Bengtsson. 1983. Lipases in milk. In Lipolytic Enzymes. B. Borgstrom and H. Brockman, editors. Elsevier/ North Holland Biomedical, Amsterdam. 206-261.

36. Bengtsson, G., T. Olivecrona, M. Hook, J. Riesenfeld, and U. Lindahl. 1980. Interaction of lipoprotein lipase with native and modified heparin-like polysaccharides. Biochem. J. 189:625-633.

37. Buonassisi, V., and M. Root. 1975. Enzymatic degradation of heparin-related mucopolysaccharides from the surface of endothelial cell cultures. Biochim. Biophys. Acta. 385:1-10.

38. Fielding, C. J., and J. M. Higgins. 1974. Lipoprotein lipase: comparative properties of the membrane supported and solubilized enzyme species. Biochemistry. 13:4324-4330.

39. Beaven, M. A., A. Robinson-White, N. B. Roderick, and G. L. Kauffman. 1982. The demonstration of histamine release in clinical conditions: a review of past and present assay procedures. Klin. Wochenchr. 60:873-881.

40. Maudsley, D. V., and Y. Kobayashi. 1977. Biosynthesis and metabolism of putrescine in the rat placenta. Biochem. Pharmacol. 24: 121-124.

41. Shakir, K. M. M., S. Margolis, and S. B. Baylin. 1977. Localization of histaminase (Diamine oxidase) in rat small intestinal mucosa: site of release by heparin. Biochem. Pharmacol. 26:23432347

42. Luk, G. D., L. J. Marton, and S. B. Baylin. 1980. Ornithine decarboxylase is important in intestinal mucosal maturation and recovery from injury in rats. Science (Wash. DC). 210:195-198.

43. Atkins, F. L., and M. A. Beaven. 1975. Studies of ornithine decarboxylase and histaminase (diamine oxidase) activities in rat thymus and their relationship to the thymus lymphocyte. Biochem. Pharmacol. 24:763-768. 